\title{
EDITORIAL
}

\section{O mundo acadêmico pode ser uma selva}

U m artigo do "Estado de São Paulo" com o título acima foi-me trazido pelo meu orientador do Mestrado em uma tarde dos anos 70, quando iniciava minha carreira acadêmica como Auxiliar de Ensino da FMRPUSP. O artigo descrevia a frustração de um profissional norte-americano que havia se transferido da empresa privada para a universidade e nesta havia encontrado um jogo de poder e um clima de intrigas tão ou mais intensos que em seu emprego anterior. Sua expectativa era de que as decisões universitárias sempre se pautassem pela ética e racionalidade, condizentes com o ideal acadêmico da busca da verdade a qualquer custo, contrastando com o ideal do lucro a qualquer preço na iniciativa privada.

Após esta primeira mensagem de advertência a respeito da pureza do meio acadêmico, recebi várias outras deste professor, hoje colega e amigo, ao longo de várias décadas de convivência universitária. Uma das pérolas que gosta de repetir, ouvida como alerta no seu próprio início na carreira universitária, refere-se exatamente aos colegas da academia: "Seus amigos não são tão bons como parecem, nem seus inimigos tão maus". Mais recentemente, este meu amigo participou de uma cena tão hilariante quanto inacreditável, em que uma velha raposa da política universitária aconselhava, em uma defesa pública de tese, um jovem pós-graduado a não ingressar na carreira acadêmica porque ela estaria povoada de serpentes e de intrigas!

\section{PROCESSOS SURREALISTAS NA UNICAMP}

Estas memórias ressurgiram agora quando fui convocado para depor em um processo movido na justiça civil contra um ex-residente e ex-pós-graduando da nossa disciplina de Imunologia Clínica da FMRP e docente da UNICAMP há mais de 10 anos. Dois colegas de sua disciplina de Imunologia Clínica e Alergia e um seu ex-orientado na Pós-Graduação acusam-no de ter falseado sua qualificação profissional no concurso de ingresso realizado há 6 anos. Declara então ter feito residência médica em Imunologia Clínica no HCRP, enquanto no certificado consta a residência em Reumatologia. Postulam a anulação do concurso, a defe- nestração do colega e a devolução de todos os salários recebidos nesse período. Figuram como co-réus da ação os então diretor da Faculdade de Medicina e o chefe do Departamento de Clínica Médica e todos os membros da banca do concurso, incluindo o atual chefe da disciplina de Imunologia Clínica da FMRP e o então chefe da disciplina de Imunologia Clínica e Alergia da UNICAMP, que, por coincidência, é um dos acusadores. Todos estão sendo responsabilizados por não terem detectado e coibido a suposta irregularidade a tempo, permitindo que o concursado progredisse na carreira universitária, realizasse um estágio de pósdoutorado no exterior, publicasse vários trabalhos científicos, formasse pós-graduandos e residentes, organizasse o serviço e se tornasse seu chefe, tudo isto pretensamente sem as qualificações que afirmou possuir. Aliás, durante seu pós-doutorado no exterior, os mesmos acusadores desencadearam na UNICAMP processo similar, que não prosperou.

A disciplina de Imunologia Clínica da FMRP iniciou suas atividades em 1975 com um conteúdo programático que incluía as doenças reumáticas, alérgicas e as imunodeficiências, ampliado a partir de 1992 pelo transplante de medula óssea (TMO), mas a residência médica foi reconhecida em 1981 apenas como Reumatologia. Apesar dos insistentes apelos da disciplina e do Hospital junto à Comissão Nacional de Residência Médica, o anacronismo e espírito burocrático desta última nunca permitiram que aquela discrepância fosse corrigida. Como consequência, muitos colegas desempenham atividades profissionais em Alergia, TMO ou Imunodeficiências portando o título de residência em Reumatologia. Poder-se-ia esperar que esta incongruência cartorial causasse problemas no competitivo mercado de trabalho médico, o que nunca ocorreu, mas sua utilização para liquidar a carreira de um docente universitário em plena maturidade é surpreendente e preocupante.

Até me assustei ao ver que meu certificado de residência médica no HCRP constava apenas Clínica Médica e não mencionava a especialidade (Hematologia, no caso). Ainda hoje, algumas especialidades, como a Terapia Intensiva e a Cirurgia de Cabeça e Pescoço, por exemplo, não têm residência reconhecida e correm também risco de questionamento legal. 


\section{OS MEIOS E OS FINS NA UNIVERSIDADE}

Ao longo de uma vivência universitária de mais de 30 anos, testemunhei muitas situações obtusamente irracionais e injustas como a relatada acima. A mais chocante delas e uma das mais precoces, foi a aposentadoria compulsória dos profs. Hélio Lourenço e Luís Hildebrando, pelo AI-5 em 1969, e a mais recente foi o descredenciamento do Hospital das Clínicas da FMRP para atendimento médico dos servidores uspianos, concretizada há poucas semanas. Em ambas, de natureza e impacto evidentemente distintos, pôde-se vislumbrar a mão de personalidades universitárias maquiavelicamente poderosas e preconceituosas. Os mais variados exemplos de intrigas acadêmicas, algumas com graves consequências para indivíduos e instituições, podem ser recolhidos repetidamente nos jornais da ADUSP, de outras entidades sindicais universitárias e até da imprensa leiga. Uma das mais ruidosas foi a recente demissão de um professor da Escola de Agronomia da USP (ESALQ), com 37 anos de carreira, acusado de malversação de algumas reses uspianas. Muitas dessas querelas, evidentemente, não ultrapassam as paredes entre as quais são geradas.

A Universidade encara com um ar de distanciamento e superioridade o clima de corrupção e de troca de favores reinante nas instituições políticas do país. Entretanto, se nossas ações fossem detalhadamente escrutinizadas, seríamos surpreendidos pela utilização, não raramente, de métodos muito semelhantes aos daquelas instituições. Elogio circular, corporativismo interno, pareceres encomendados, flerte com empresas privadas, nepotismo, técnica do rolo compressor, assédio sexual e retaliações pessoais não são estranhos ao ambiente universitário. Com raras exceções patológicas, pode-se encontrar, em todas estas ações, justificativas filosóficas de defesa do ideal acadêmico. Professores foram aposentados para purgar a universidade de influências ideológicas malignas, o convênio SISUSP foi rompido para economizar verbas públicas, o colega da UNICAMP (ou o da ESALQ) foi processado para afastar um incompetente (ou um desonesto) da academia, e assim por diante. Entretanto, as verdadeiras motivações, usualmente bem mais mundanas do que filosóficas, muitas vezes ficam perdidas nos meandros dos processos e das mentes que os manipularam.

Ao contrário do legislativo, atividade política da Universidade, onde são gerados a grande maioria de seus conflitos, existe para reger suas atividades-fim (ensino, investigação e prestação de serviços). A maioria destas requer competência técnica, compromisso institucional e, como se tem reconhecido atualmente, inteligência emocional. Esta última implica reconhecer as qualidades e limitações de si próprio e dos cole- gas, adequando-as ao trabalho integrado para extrair o máximo de cada um com o mínimo de estresse. Quanto mais complexa a tarefa, mais necessária esta adequação de potencialidades para a consecução dos objetivos pretendidos. A continuidade do transplante de medula óssea no HCFMRP, por exemplo, tem exigido, além de uma reunião semanal da equipe para analisar seus conflitos, uma atenção permanente ao funcionamento harmônico da mesma. Descuidar-se desta harmonia interna tem causado o fracasso de muitas estruturas tecnicamente competentes.

A reforma universitária do final dos anos 60 substituiu o poder draconiano dos catedráticos pela organização parlamentar dos colegiados. Esta democratização, indubitavelmente benéfica para os rumos da Universidade, pressupõe o envolvimento de uma proporção considerável do corpo docente no gerenciamento da instituição. Muitos remanescentes do regime autocrático e seus seguidores mais jovens ainda hoje têm grande dificuldade de se adaptar a um regime de gestão coparticipativa. Outros mais talhados demonstram pouco interesse de engajamento, preferindo dedicarse às suas próprias atividades, cedendo espaço a lideranças oportunistas. Entre estas, combinações particularmente nocivas e altamente geradoras de conflitos são as do dirigente técnica e emocionalmente medíocre, o qual, não raro, vemos guindado a altos cargos na hierarquia e a do que se afasta definitivamente das atividades-fim, dissocia-se destas, profissionaliza-se na burocracia e passa a se pautar exclusivamente pela sua ascenção política. Somam-se a estas, que não são mutuamente exclusivas, o profissional muito capaz em sua área de atuação específica, mas emocionalmente e filosoficamente despreparado para a administração universitária. Podemos vislumbrá-los desempenhando papel crítico em grande número de conflitos no meio acadêmico, como os exemplificados neste artigo. Os colegiados, onde estes conflitos poderiam ser trabalhados e resolvidos, têm papel limitado, ou são excluídos em decisões executivas incoerentes ou servem apenas para sacramentá-las.

A prática política no interior da Universidade, infeliz e inevitavelmente, não difere muito da encontrada nas instituições políticas do país. O meio acadêmico, entretanto, tem maiores recursos e exigências para não se transformar numa fogueira de vaidades ou numa carnificina predatória que comprometa seus nobres objetivos. Para isto, tem que cuidar melhor da sua inteligência emocional.

$$
\begin{aligned}
& \text { Prof. Dr. Júlio C. Voltarelli } \\
& \text { Editor }
\end{aligned}
$$

